\title{
Determining Changes in Land Use Structure in Małopolska Using Statistical Methods
}

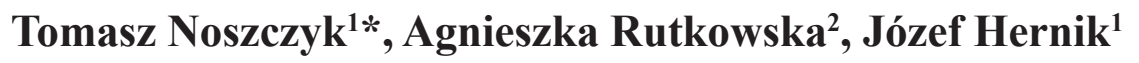 \\ ${ }^{1}$ Department of Land Management and Landscape Architecture, Faculty of Environmental Engineering \\ and Land Surveying, University of Agriculture in Krakow \\ Balicka 253C, 30-149 Kraków, Poland \\ ${ }^{2}$ Department of Applied Mathematics, Faculty of Environmental Engineering and Land Surveying, \\ University of Agriculture in Krakow, \\ Balicka 253C, 30-198 Kraków, Poland
}

Received: 16 June 2016

Accepted: 30 August 2016

\begin{abstract}
For this paper we studied changes in areas of four land use variables were in the Małopolska Voivodeship of Poland. The following annual land use time series were used: surface area of agricultural lands, surface area of forest lands and wooded and bushy areas, surface area of built-up and urbanized lands, and surface area of wasteland. The autocorrelation structure and the temporal changes were studied using the autocorrelation function (ACF) and the Mann-Kendall test for monotonic trend, respectively. The parameters of the deterministic component of the time series were identified using the method of least squares. The Akaike information criterion was used in the final choice of this component. The stochastic component was studied using statistical tests. Coefficient of determination and mean absolute relative error were used as diagnostic measures of the models. Results show a significant dependence of the current land use values on the past values from the previous two years. A negative trend was observed in the series of agricultural land surface area and a positive trend in the other three series. Temporal evolution of the series includes both quadratic trend and Gaussian white noise. In conclusion, temporal monotonic changes of the four land use variables were demonstrated in Małopolska. Some options for land use decision-making are clarified.
\end{abstract}

Keywords: land use, land use time series, statistical model, autocorrelation, trend analysis

\section{Introduction}

Numerous studies around the world have attempted to understand processes and phenomena of changes in land use structures [1-4]. These changes result from variable socioeconomic, environmental, political, technological,

*e-mail: t.noszczyk@ur.krakow.pl and cultural conditions [5], and drive global changes in the environment [6-7]. Land use impacts multiple environmental factors, including water, soil, and air quality, which in turn are related to the climate and ecosystem [8-10]. It is, however, uncertain how land use patterns in individual regions will change as a result of various trends (such as urbanization). Multiple factors, including environmental (for example topography, soil fertility), socioeconomic (for example distribution of income), spatial planning, and politics and trade have a 
significant impact on shaping of appropriate land use patterns [11].

In recent years, statistical models have been widely used to study changes in land use [8, 12-15]. Modelling is an important technique for determining land use status, assessing dynamics and trends in land use $[12,16]$, and searching for primary directions in planning $[4,17]$. Thus, statistical analysis of land use change is increasingly more important for sustainable land management and is attracting ever more attention in scientific circles [18-19].

Literature abounds in various examples of applications of modelling in studying land use change. Kaimowitz and Angelsen [20] and Lambin [21] use modelling to monitor tropical deforestation; Lambin et al. [8] for intensification of agriculture. Michetti and Zampieri [19] and Briassoulis [22] provided a wide discussion of numerous types of applied models, and Verburg et al. [13] identified problems and indicated requirements for improving land use models. According to Overmars et al. [23] (p. 257), "land use change models represent part of the complexity of land use systems" and facilitate testing land use sensitivity to changes in selected variables. They are also used as a point of departure in environmental impact studies [7, 24].

The majority of studies have assumed, however, that modelling of land use change should be performed for extensive periods of time $[3,25]$. This would be a difficult challenge in the case of Poland owing to the lack of appropriate cartographic data and coherent cadastral data. Poland's cadastre situation is complicated because from 1772 to 1918 its territory was partitioned among three invaders: Prussia, Russia, and Austria-Hungary, each with their own cadastral system. World War II also brought territorial changes to Poland. The country's surface area shrank, its borders were moved, and new areas in the north and west were incorporated into its territory [26]. It was not until the 1950s that maps and registers of Prussian and Austrian cadastres were used (as source and technical materials) to create a new, uniform land register in postwar Poland [27].

The situation was further negatively impacted by the fact that during this period administrative borders of the nation-state and boundaries of individual regions were changed multiple times, which prevented, for example, a comparison of data for areas of individual patterns of land use. The last administrative reform in Poland took place in 1998 and boundaries of territorial units have been stable only since 1999. Another issue is the fact that cadastral data published before 2000 is not always continuous data, which is required for modelling. Since 2000, public cadastral data for land use has been available every year and its content can be analyzed. Therefore, authors of this paper decided to create a short-term model that uses continuous cadastral data, which is also used in studies on land use change [28-29], and decided not to analyze the spatial location of changes of land use, but to focus on statistical analysis of trends.

The goal of this paper is to analyze changes in the structure of land use in the Małopolskie Voivodeship (Poland) in 2002-15 and propose an approach to monitor

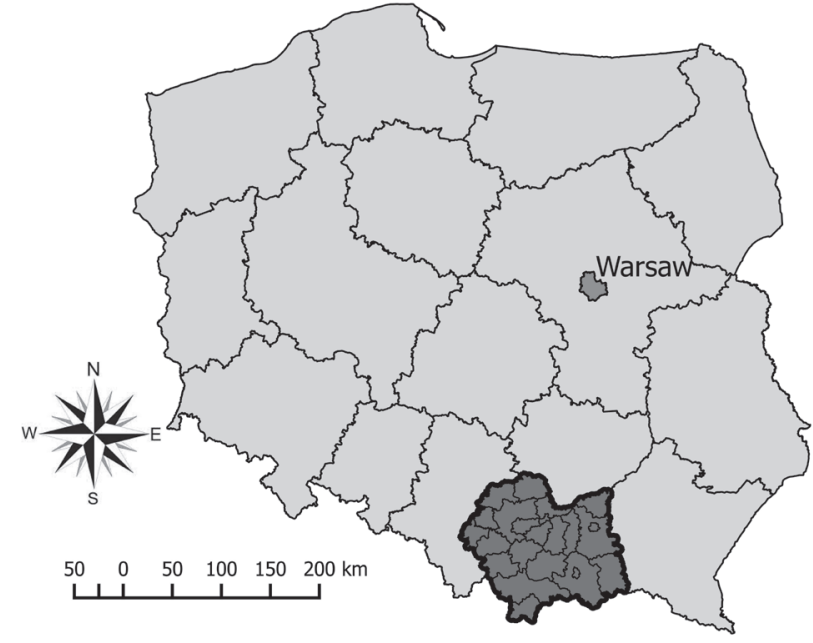

Fig. 1. Location of the Małopolskie Voivodeship - the studied area.

the change. To this end, statistical methods were applied and models that describe changes in the study area developed.

\section{Materials and Methods}

\section{Study Area}

The study was performed in the Małopolskie Voivodeship, southern Poland (Fig. 1). The Małopolska region takes up 15,183 $\mathrm{km}^{2}$ (about $5 \%$ of Poland's surface area) and is inhabited by about 3.37 million people (about $8 \%$ of the Polish population) [30-31]. It comprises 19 districts [or powiat, a second-tier administrative unit], including three towns with district rights: Kraków, Nowy Sącz, and Tarnów.

The Małopolskie Voivodeship is an interesting study object thanks to its substantial biodiversity [32]; diverse terrain, hydrology, and geology [33]; diverse spatial structure of rural areas [34-35]; and land use diversity

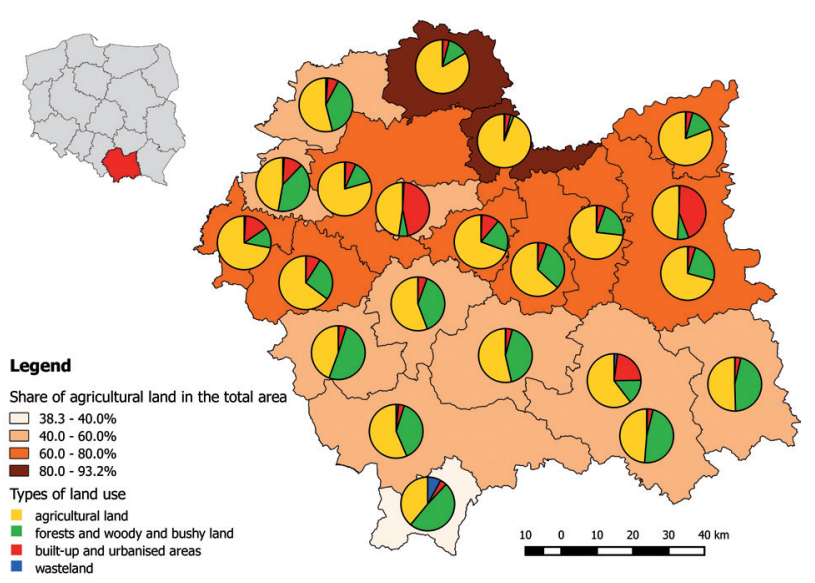

Fig. 2. Types of land use in the Małopolskie Voivodeship in 2015. 
[36]. Northern Małopolska is dominated by agricultural land (more than 60\%). The central part of the Voivodeship (including the Kraków area) is the most urbanized, and the southern area is dominated by forests (Fig. 2) [37]. The spatial structure of rural areas in Małopolska is disadvantageous, which results from substantial fragmentation and scattering of land [34]. Particularly unfavorable land location complicates the matter further as the mean number of parcels per one holding is above 7 [35].

The environmental and natural assets of Małopolskie Voivodeship are composed of six national parks, 11 natural landscape parks, 10 protected landscape areas, and 84 nature reserves. The environment of as much as $53 \%$ of Małopolska's surface area is protected. Babia Góra and Tatra National Parks are UNESCO biosphere reserves [31], meaning that they are unique on a global scale and have exceptional environmental assets. In the Małopolskie Voivodeship area, at the Polish-Slovak border, there are the Tatra Mountains (2,655 $\mathrm{m}$ a.s.1.), the highest range of the Carpathian Mountains, mostly covered in beechfir, and spruce forests [38]. This region is also considered strategic due to its substantial historical, cultural, and tourist values [31].

\section{Data}

The study involves four variables: $X_{1}$ - surface area of agricultural lands, $X_{2}$ - surface area of forest lands and wooded and bushy areas, $X_{3}$ - surface area of built-up and urbanized lands, and $X_{4}$ - surface area of wasteland. The analyzed period was 2002-15 (as per January 1). The reason for selecting this time period was the new administrative division of Poland into 16 Voivodeships (since 1 January 1999) and stable land and property register regulations at that time. The current state was assessed based on land and property registry data provided by the Marshall Office of the Małopolskie Voivodeship, which collects the data for the whole study area.

Due to the fact that as of 1 January 2002 Polish local government administration was not fully adjusted to modified regulations on preparing summaries of data included in land and property registers, the value of

Table 1. Statistical characteristics.

\begin{tabular}{|c|c|c|c|c|}
\hline & \multicolumn{4}{|c|}{ Variables } \\
\hline Characteristics & $X_{1}$ & $X_{2}$ & $X_{3}$ & $X_{4}$ \\
\hline$n$ & 13 & 14 & 14 & 14 \\
\hline Mean [ha] & 934,406 & 459,326 & 83,041 & 10,724 \\
\hline Median [ha] & 936,718 & 460,148 & 81,769 & 11,270 \\
\hline $\begin{array}{c}\text { Standard deviation } \\
\text { [ha] }\end{array}$ & 7,010 & 3,656 & 6,233 & 1,070 \\
\hline $\begin{array}{c}\text { Coefficient of } \\
\text { variation (CV) } \\
{[\%]}\end{array}$ & $0.75 \%$ & $0.80 \%$ & $7.51 \%$ & $9.98 \%$ \\
\hline \multicolumn{2}{|c|}{ [\%] }
\end{tabular}

variable $X_{1}$ for 2002 was underestimated. Therefore, this particular value was excluded from further analysis. The study period for variable $X_{1}$ was 13 years (2003-15) and 14 years (2002-15) for the other variables: $X_{2}, X_{3}$, and $X_{4}$. Sample characteristics of variables $X_{1}, X_{2}, X_{3}$, and $X_{4}$ are shown in Table 1.

For all samples (apart from variable $X_{3}$ ), the mean value is less than the median value, which reflects the asymmetry of the empirical distribution function. Moreover, all variables have small variability, which is reflected in the low value of the standard deviation in comparison to the mean value and very low $\mathrm{CV}$. The variability of $X_{3}$ and $X_{4}$ is much higher than that of $X_{1}$ and $X_{2}$ (Table 1).

\section{Methods}

Following the creation of a database with four variables, we commenced the next stage. Its purpose was to determine the trend of changes in land use structure and construct models that best describe these changes. For this purpose, statistical methods were applied.

To test whether $X_{t}$ contained a monotonic component in the mean value, the following hypotheses were formulated: the null hypothesis that there is no monotonic trend against the alternative that an increasing (decreasing) trend exists. A nonparametric method, namely the Mann-Kendall test, was used in this paper [39-40]. The test has been widely applied for detection of monotonic land use changes [4143]. It is also a very popular method in environmental studies [44-47]. If the sample is $\left\{y_{1}, \ldots, y_{n}\right\}$, then the MannKendall (MK) statistic has the following form:

$$
S=\sum_{i=1}^{n-1} \sum_{j=i+1}^{n} \operatorname{sgn}\left(y_{j}-y_{i}\right)
$$

Positive (negative) value of $S$ suggests an increasing (decreasing) trend.

The variance of $S$ is $\operatorname{Var}(S)=\frac{n(n-1)(2 n+5)}{18}$. The standardized $U$-statistic is normally distributed and equals:

$$
U=\left\{\begin{array}{lll}
\frac{S-1}{\sqrt{\operatorname{Var}(S)}} & \text { if } & S>0 \\
0 & \text { if } & S=0 \\
\frac{S+1}{\sqrt{\operatorname{Var}(S)}} & \text { if } & S<0
\end{array}\right.
$$

The p-value was calculated as $F(U)$ (if $U<0$ ) and $1-F(U)$ (if $U>0$ ), where $F$ is the cumulative distribution function of the standardized normal distribution. The null hypothesis was rejected if $p$-value $<\alpha$ where $\alpha$ is the significance level.

The MK test revealed a decrease of the power in the presence of autocorrelation [23, 47-50], which means that the existing trend can be undetected by the test if the series contains autocorrelated data. The decrease of power results 
from the underestimation of variance $\operatorname{Var}(S)$ when data is autocorrelated. Then the effective number of sample elements is lower than $n$. Various authors recommend the use of correction factors to $\operatorname{Var}(S)$ due to autocorrelation $[49,51-52]$.

Preliminary calculations revealed that all data series were serially correlated in this study because by using the Ljung-Box test [53] the autocorrelation function ACF was revealed to be significant for certain lags. Therefore, the correction factor was used, $\operatorname{Var}^{*}(S)=\frac{n}{n^{*}} \operatorname{Var}(S)$ where $n^{*}$ is the effective number of observations given as [51]:

$$
n^{*}=\frac{n}{1+\frac{2}{n} \sum_{j=1}^{n-1}(n-j) p_{j}}
$$

...where $\rho_{j}$ is the autocorrelation coefficient at lag $j$.

When a trend was revealed by the MK test, the regression model with the deterministic trend was considered as:

$$
Y_{t}=f(t)+\varepsilon_{t}
$$

...where $t \in T, T$ is the period of observation, $Y_{t}$ is the random variable at time $t$, and $\varepsilon_{t}$ is a residual. The variables $\varepsilon_{t}(t \in T)$ are independent, normally distributed (Gaussian white noise) with mean value equal to 0 . The component $f(t)$ represents the deterministic part of variable $X_{t}$, while $\varepsilon_{t}$ is the stochastic part.

(A) Agricultural land

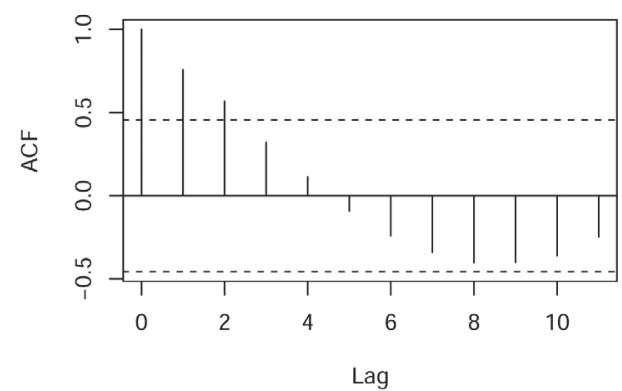

(C) Built-up and urbanised areas

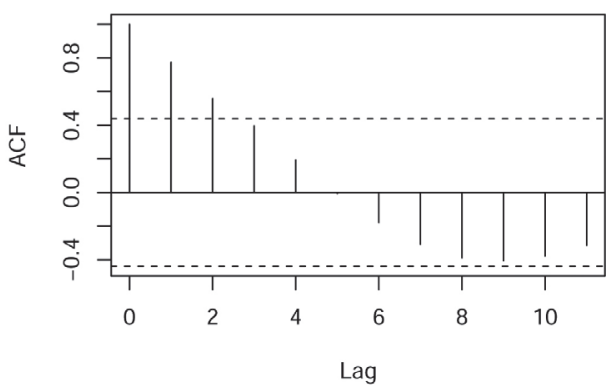

A linear, quadratic, power, and logarithmic function were considered as $f$. Parameters of $f$ were estimated using the method of least squares (LS).

The final choice was based on the Akaike information criterion [54]. This criterion becomes:

$$
A I C=n \cdot \ln \frac{\sigma^{2}}{n}+2 k
$$

...for the regression model with normally distributed residuals, where $\sigma^{2}$ is the sum of squares of residuals and $k$ is the number of parameters.

The lowest AIC value indicates the best fit.

We faced the problem of small samples, which might result in unreliable conclusions from the MK test. To assess whether the test is credible enough, the power of the test was estimated using the Monte Carlo simulation method [46]. The power is a measure of ability of the test to detect a trend if this trend really exists. If power is near 1 then the test is powerful and if power is near zero then the test is not reliable. Usually, a series several dozen years in length is needed for the MK test to be powerful. However, if a trend is strong, i.e. if the steepness of function $f$ is high, then the length can be lower. In the simulation process, $N=10,000$ repetitions were used. The estimates of the parameters of trend $f$ and of standard deviation of $\varepsilon_{t}$ were derived first. Then, artificial series similar to ours with the same (i) relative change of the expected value and (ii) coefficient of variation were generated. Next, the MK test was used for these series. The number of repetitions $L$ where the trend was detected divided by $N$ was used as the power estimate. Afterward, to account for variability

(B) Forests and woody and bushy land

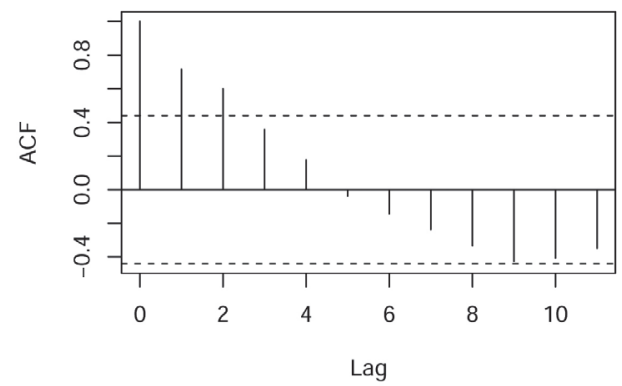

(D) Wasteland

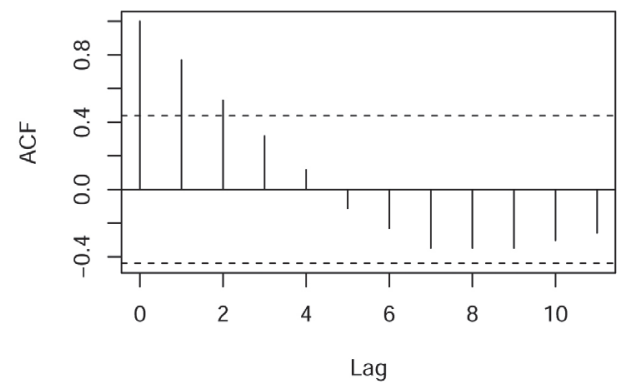

Fig. 3. ACF of variables: (A) $X_{1}$, (B) $X_{2}$, (C) $X_{3}$, (D) $X_{4}$. 
of estimates, we assumed bias of estimation $\pm 20 \%$ for every parameter and the procedure was repeated. The correction factor due to autocorrelation was also used. As a final result we obtained the power estimates to be located between 0.91 and 1 over all series studied. Due to very high values of these estimates, we can conclude that despite the small samples we can rely on results of the MK test in this study.

More details about the simulation procedure are shown in the Appendix.

The following diagnostic methods were used for residuals: the Shapiro-Wilk (SW) test for normality, the t-test of the mean value equal to 0 , and the Ljung-Box test of no autocorrelation. Additionally, the following diagnostic measures were calculated: the coefficient of determination $\mathrm{R}^{2}$ and the mean absolute relative error (MARE).

All calculations were carried out in R program [55].

\section{Results and Discussion}

The ACF is significant for all time series at lag $=1,2$ (Fig. 3) because ACF is higher than the confidence limit at these lags $(\alpha=0.1)$. Hence, values of the variables in a given year depend on their values in the previous year and the year before that. Therefore, because the variables are serially dependent, the MK test for trend with the correction factor had to be used. A monotonic trend was detected in all four land-use time series. The trend was decreasing for the $X_{1}$ variable and increasing for the $X_{2}, X_{3}$, and $X_{4}$ variables (Fig. 4).

(A) Agricultural land

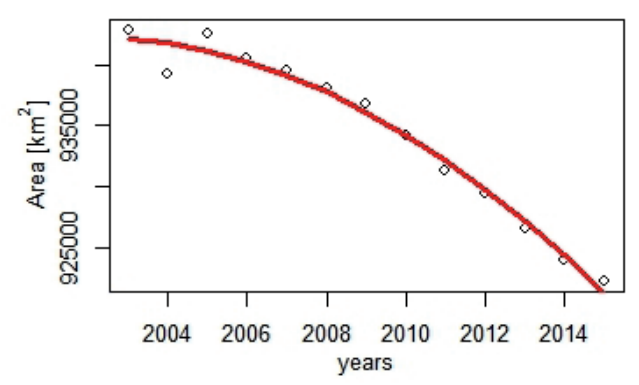

(C) Built-up and urbanised areas

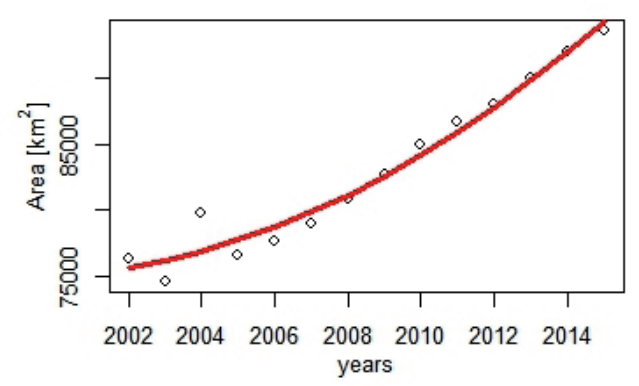

The AIC value (5) for the model with the linear, quadratic, power, and logarithmic function was equal to 237.58, 223.33, 271.45, and 237.65 for $X_{l} ; 237.42,236.59$, 239.32, and 237.39 for $X_{2} ; 250.94,243.61,281.64$, and 251.00 for $X_{3}$; and 219.18, 198.98, 235.93, and 219.14 for $X_{4}$, respectively. The lowest values were obtained for the quadratic function. Therefore, the final model was based on the trend $f(t)=a t^{2}+b t+c$.

We obtained the following regression equations: $X_{1}=-121.5938700299 t^{2}+486,828.7028219 t-$ $486,340,046.80001$

$X_{2}=-27.2037364011 t^{2}+110,120.35638444 t-$ $110,975,131.863772$

$X_{3}=73.6706151099 t^{2}-294,493.556269621 t+$ $294,379,567.50928$

$X_{4}=-30.3008241758 t^{2}+121,943.8986263710 t-$ $122,677,390.542854$

The time series plots and the fitted regression functions are depicted in Fig. 4.

The $U$-statistic and the p-value of the MK test, the regression parameter estimates, and the diagnostic measures are presented in Table 2 .

Diagnostic measures show a high quality of the model because $\mathrm{R}^{2}$ is very high and MARE is very low. Additionally, the SW test did not reject the hypothesis of normality of the distribution function of residuals because the $p$-values are greater than $\alpha$. Residuals are not autocorrelated, which is shown in Figure 5. The test of significance shows that the mean values of residuals are not far from 0 for all four variables, because the $p$-values of the t-test are greater than 0.9. Thereby, residuals form the Gaussian white noise.

\section{(B) Forests and woody and bushy land}

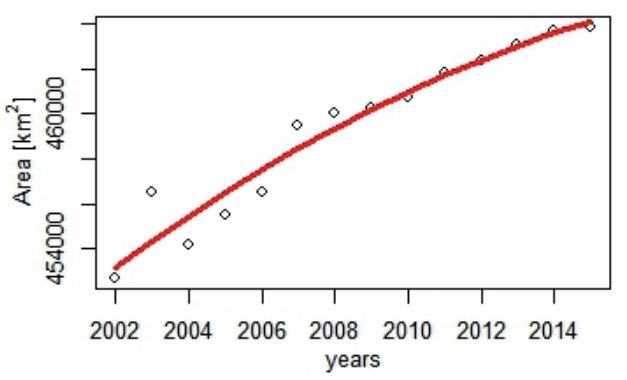

(D) Wasteland

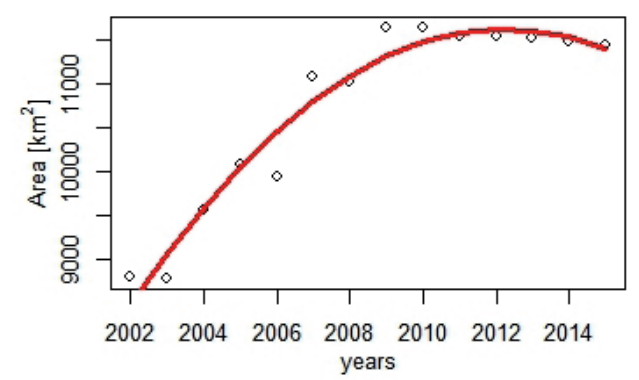

Fig. 4. Time series plot and regression function plot of variables: (A) $X_{1}$, (B) $X_{2}$, (C) $X_{3}$, (D) $X_{4}$. 
Table 2. The $U$-statistic, the p-values of the MK and SW tests, and diagnostic measures.

\begin{tabular}{|c|c|c|c|c|}
\hline \multirow{2}{*}{} & \multicolumn{4}{|c|}{ Variables } \\
\cline { 2 - 5 } & $\mathrm{X}_{1}$ & $\mathrm{X}_{2}$ & $\mathrm{X}_{3}$ & $\mathrm{X}_{4}$ \\
\hline$U$ & -2.36 & 2.51 & 2.44 & 1.38 \\
\hline p-value (MK test) & 0.009 & 0.006 & 0.007 & 0.084 \\
\hline p-value (SW test) & 0.21 & 0.21 & 0.17 & 0.30 \\
\hline $\mathrm{R}^{2}$ & 0.98 & 0.94 & 0.97 & 0.95 \\
\hline MARE & $0.08 \%$ & $0.13 \%$ & $1.02 \%$ & $1.63 \%$ \\
\hline Trend $f$ & $\downarrow$ & $\uparrow$ & $\uparrow$ & $\uparrow$ \\
\hline
\end{tabular}

Results of the study indicate that in 2002-15 the most profound changes occurred in built-up and urbanized lands, whose surface area increased by 17,342 ha, and in agricultural lands, whose surface area decreased by 12,265 ha. The shape of the regression curve indicates a strong upward trend for built-up and urbanized areas and a strong downward trend for agricultural land over the study period (Fig. 4).

The process of the decline of agricultural land surface area noted in Małopolska is consistent with the global trend. It is also applicable to the world [56], Central and Eastern Europe, where agriculture is dominant [5658], and in Poland [59-61]. Studies by Lowicki [62] and Zydroń and Hausa [63] for Wielkopolska and Senetra et al. [64] conducted in the Warmia and Mazury region confirm similar changes in the structure of land use to the ones in the Małopolskie Voivodeship as well.

(A) Agricultural land

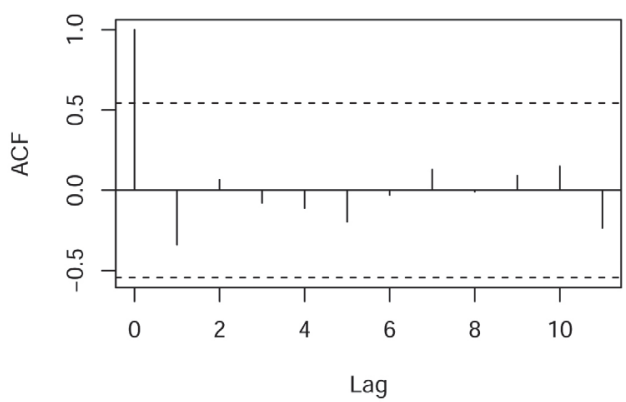

(C) Built-up and urbanised areas

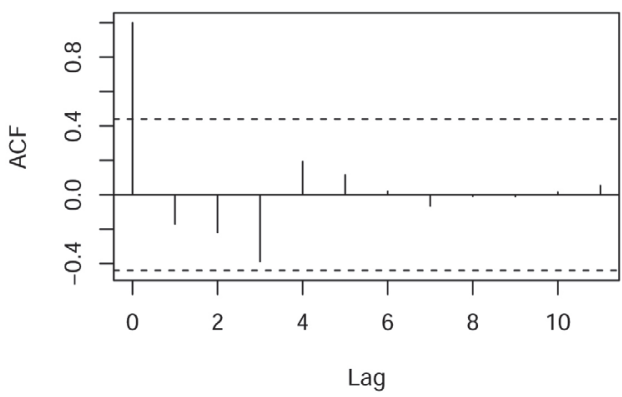

Apart from the decrease in agricultural land surface area, wasteland surface area increased in Małopolska by 2,664 ha in the study period. The regression curved indicates that there was a major trend toward an increase of the surface area of the wasteland until 2009. Then it stabilized, and since 2010 the surface area has been decreasing slightly (Fig. 4).

The processes are closely interrelated. Unprofitability of agricultural production and diverse spatial structure of agricultural holdings in the Małopolskie Voivodeship have resulted in a gradual decrease of farming [65]. This in turn brings about a decrease of the surface area of agricultural lands and an increase of the surface area of wasteland. Socioeconomic changes that commenced in the 1980s resulted in a decrease in the interest in agriculture and agricultural use of land, and the traditional method of land use is currently shunned [32]. The cause of unprofitability of agricultural production in Poland, in particular on low-quality lands, was the introduction of a free-market economy in agriculture and the importation of subsidized food products from Western Europe [59-60]. This has resulted in impoverishment of rural areas in particular and the disappearance of a number of plant and animal species, which decreases biodiversity [32]. Łowicki [62] suggests that the competitive pressure of European countries on Polish agriculture necessitated intensification of production in the form of increased spending and extended cultivated areas. Therefore, production was ceased in small agricultural holdings that were unable to resist increasing competition, were unfavourably located, or had a poor agrarian structure

(B) Forests and woody and bushy land

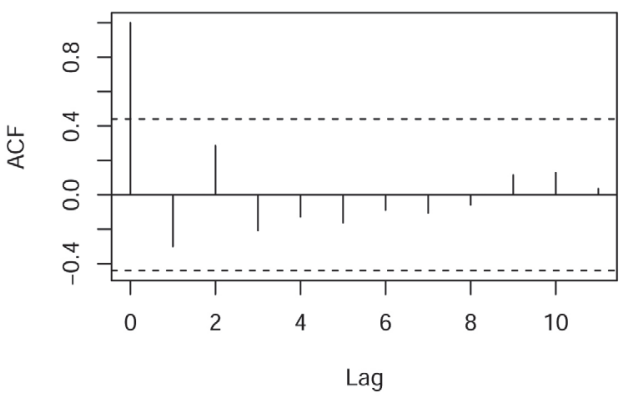

(D) Wasteland

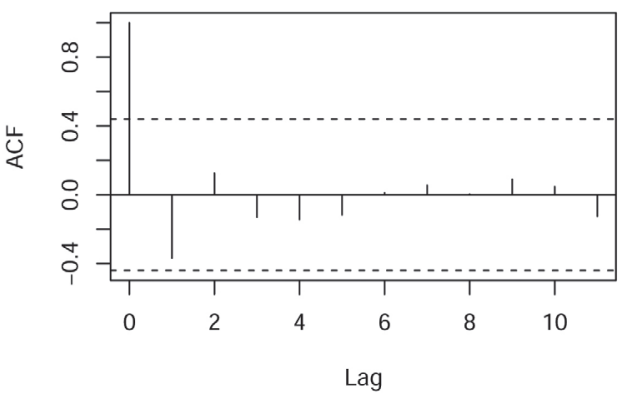

Fig. 5. ACF of residuals: (A) $X_{1}$, (B) $X_{2}$, (C) $X_{3}$, (D) $X_{4}$. 
[62]. Some of them had to switch their production and change land use.

An important contributor to the process of land use change in Małopolska was also growth of built-up areas caused primarily by socioeconomic changes after the 1989 transformation. The core driving force of the changes was growth of the residential construction industry, trade areas, and transportation infrastructure $[59,66]$. In 2002-15, the area of built-up and urbanized lands in the Małopolskie Voivodeship increased by 17,342 ha and continued to increase significantly throughout the study period (Fig. 4). These areas developed mainly at the expense of agricultural lands as opposed to forest lands, which are seldom urbanized. The increase of builtup areas focused mainly around larger towns, including Kraków (Fig. 6). Yet urbanization occurs far from large agglomerations as well. This happened around smaller towns (Tarnów, Nowy Sącz, Wieliczka) or in rural communes [gmina - a third-tier administrative unit] bordering Kraków (Zielonki, Michałowice) (Fig. 6). A similar issue with conversion of agricultural lands into built-up lands has been noted, for instance, in Germany and China [67].

Afforestation was another form of change in land use. An upward trend for forest land surface area was found in the Małopolskie Voivodeship (Fig. 4). Forests and forest lands take up about $30 \%$ of the total surface area of the Małopolska region. A decrease in profitability of agriculture and environmental protection requirements contributed to big efforts to increase the share of forests in total surface area $[62,68]$. The main instrument regulating the afforestation activity in Poland is the National Programme for the Augmentation of Forest Cover, which assumes an increase in the forested area in Poland as a whole to $33 \%$ by 2050 [35]. Additionally, Poland's membership in the EU and implementation of the Common Agricultural Policy (CAP) contributed to constant expansion of forest coverage as well [64]. CAP offers various funding mechanisms of afforestation that were included in the Rural Development Programme. The Małopolskie Voivodeship is a unique area in terms of the environment with its numerous national parks, natural landscape parks, and mountain ranges located in its southern part, including the Tatras, Pieniny, and Beskid Sądecki. These areas favour forests and forest land. Therefore, the largest share of them can be found in the southern part of the Voivodeship where mountain ranges occur.

\section{Conclusions}

Our study has yielded the following conclusions:

1. Areas of specific types of land use exhibit monotonic changes in the period of 2002-15 with a negative trend for agricultural land and a positive trend for the other variables (forest lands and wooded and bushy areas, built-up and urbanized lands, and wasteland).

2. The above-mentioned trends are quadratic dependences.

3. Values of the variables in a given year depend on their values in the previous year and the year before that.

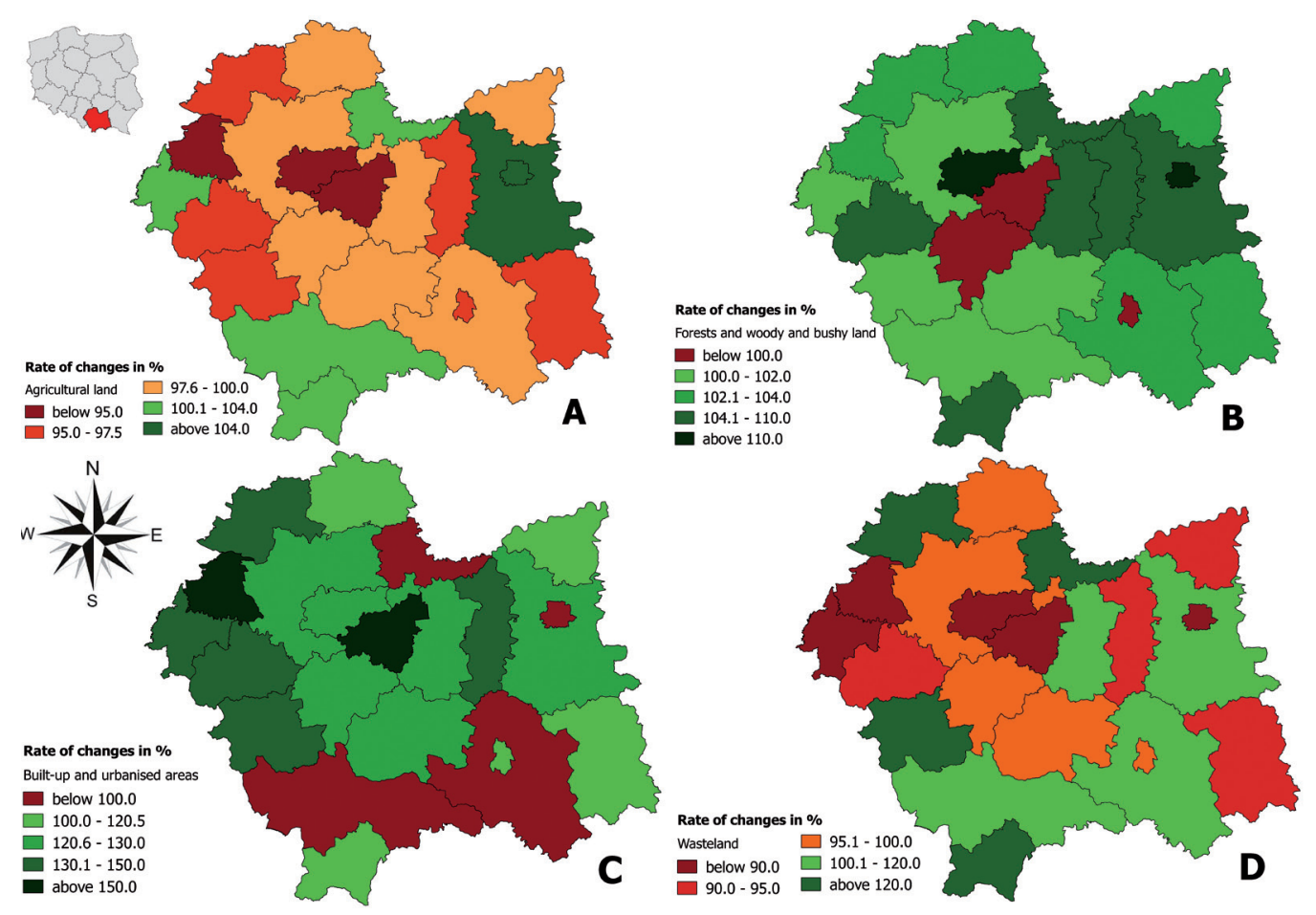

Fig. 6. Rates of change (\%) in agricultural land (A), forests and woody and bushy land (B), built-up and urbanized areas (C), and wasteland (D) in the Małopolskie Voivodeship between 2002 and $2015(2002=100 \%)$. 
4. Changes in land use structure can be analyzed using statistical methods.

The statistical models constructed in the study may undoubtedly support the process of monitoring land use change. They facilitate determining a trend and taking appropriate corrective actions, if necessary. These may include limiting the number of permits to exclude land from agricultural production or adequate shaping of a region's spatial policy.

\section{Acknowledgements}

This Research was financed by the Ministry of Science and Higher Education of the Republic of Poland (projects No. BM - 4386/KGPiAK/2016, DS 3371/KGPiAK/2016 and DS 3376/KZM/2016).

\section{Appendix}

We assumed model (4) with linear trend $f(t)=c t+d$. This model was used for simplicity, instead of the quadratic model, which did not have any noticeable impact on the power estimates. The simulation experiment was based on model (4'): $V_{t}=b t+U_{t}$, where $\quad b=\frac{c}{d} \quad$ and $U_{t}=1+\frac{1}{d} \cdot \varepsilon_{t}$. This model is equivalent to (4) in the sense that (i) the relative changes of the expected values of $V_{t}$ and of $Y_{t}$ and (ii) the coefficients of variation of $V_{t}$ and of $Y_{t}$, are equal to each other. Thus, the model (4') yields a change similar to (4). The model (4') enables inclusion of two parameters, namely standard deviation $\sigma$ of $\varepsilon_{t}$, responsible for variation of $Y_{t}$ and parameter $b$, responsible for strength of the trend, instead of three parameters $c, d$, and $\sigma$. Shortly speaking, we wish the new model to be independent of the initial expected value to provide results of the power assessment useful for various time series. The simulation experiment was carried out as follows. We generated $N=10,000$ realizations of Gaussian random variable $U_{t}$ of length 14 years (i.e., $t=0, \ldots, 13$ ) using a random number generator (Marsaglia-Multicarry). Then we composed $V_{t}$ using formula (4'). For every $V_{t}$ the MK

test was conducted. Finally, we estimated power $=\frac{L}{N}$.

Afterward, to account for variability of estimates, we assumed bias of estimation $\pm 20 \%$ for every parameter and the procedure was repeated. At each stage we used the correction factor for an effective number of observations (Equation (3)).

\section{References}

1. BIČÍK I., HIMIYAMA Y., FERANEC J., KUPKOVÁ L. Land use/cover changes in selected regions in the world
- IX. IGU Commission on LUCC, Charles University in Prague: Prague, 2014.

2. ATIK M., ALTAN T., ARTAR M. Land Use Changes in Relation to Coastal Tourism Developments in Turkish Mediterranean. Polish Journal of Environmental Studies, 19, 21, 2010.

3. BIČÍK I., KUPKOVÁ L., JELEČEK L., KABRDA J., ŠTYCH P., JANOUŠEK Z., WINKLEROVÁ J. Land use changes in the Czech Republic 1845-2010: Socioeconomic driving forces. Springer International Publishing: Switzerland, 2015.

4. MURRAY-RUST D., RIESER V., ROBINSON D.T., MILICIC V., ROUNSEVELL M. Agent-based modelling of land use dynamics and residential quality of life for future scenarios. Environmental Modelling \& Software, 46, 75, 2013.

5. BÜRGI M., STRAUB A., GIMMI U., SALZMANN D. The recent landscape history of Limpach valley, Switzerland: Considering three empirical hypotheses on driving forces of landscape change. Landscape Ecology, 25, 287, 2010.

6. DRUGA M., FALTAN V. Influences of environmental drivers on land cover structure and its long-term changes: A case study of the villages of Malachov and Podkonice in Slovakia. Moravian Geographical Reports, 22, 29, 2014.

7. SCHALDACH R., ALCAMO J., KOCH J., KOELKING C., LAPOLA D.M., SCHUENGEL J., PRIESS J.A. An integrated approach to modelling land-use change on continental and global scales. Environmental Modelling \& Software, 26, 1041, 2011.

8. LAMBIN E.F., ROUNSEVELL M.D.A., GEIST H.J. Are agricultural land-use models able to predict changes in landuse intensity? Agriculture Ecosystems \& Environment, 82, 321, 2000.

9. MOONEY H.A., DURAIAPPAH A., LARIGAUDERIE A. Evolution of natural and social science interactions in global change research programs. Proceedings of the National Academy of Sciences of the United States of America, 110, 3665, 2013.

10. LOUCA M., VOGIATZAKIS I.N., MOUSTAKAS A. Modelling the combined effects of land use and climatic changes: Coupling bioclimatic modelling with Markov-chain Cellular Automata in a case study in Cyprus. Ecological Informatics, 30, 241, 2015.

11. STÜRCK J., LEVERS C., VAN DER ZANDEN E.H., SCHULP C.J.E., VERKERK P.J., KUEMMERLE T., HELMING J., LOTZE-CAMPEN H., TABEAU A., POPP A., SCHRAMMEIJER E., VERBURG P. Simulating and delineating future land change trajectories across Europe. Regional Environmental Change, 1, 2015.

12. INDROVÁ M., KUPKOVÁ L. Land use changes in Prague suburban area according to different prediction modelling approaches. Geografie, 120 (3), 422, 2015 [In Czech].

13. VERBURG P.H., SCHOT P.P., DIJST M.J., VELDKAMPA. Land use change modelling: Current practice and research priorities. GeoJournal, 61 (4), 309, 2004.

14. MOLOWNY-HORAS R., BASNOU C., PINO J. A multivariate fractional regression approach to modeling land use and cover dynamics in a mediterranean landscape. Computers Environment and Urban Systems, 54, 47, 2015.

15. GONG J., HU Y., LIU M., BU R., CHANG Y., BILAL M., LI CH., WU W., REN B. Land Use Regression Models Using Satellite Aerosol Optical Depth Observations and 3D Building Data from the Central Cities of Liaoning Province, China. Polish Journal of Environmental Studies, 25, 1015, 2016. 
16. MIRKATOULI J., HOSSEINI A., NESHAT A. Analysis of land use and land cover spatial pattern based on Markov chains modelling. City, Territory and Architecture, 2, 4, 2015.

17. VELDKAMP A., LAMBIN E.F. Predicting land-use change. Agriculture Ecosystems \& Environment, 85, 1, 2001.

18. ZHANG Y., GAO Y., GAO B., PAN Y., YAN M. An efficient graph-based method for long-term land-use change statistics. Sustainability, 8, 9, 2016.

19. MICHETTI M., ZAMPIERI M. Climate-Human-Land Interactions: A Review of Major Modelling Approaches. Land, 3 (3), 793, 2014.

20. KAIMOWITZ D., ANGELSEN A. Economic Models of Tropical Deforestation - A Review. Center for International Forestry Research: Bogor (Indonesia), 1998.

21. LAMBIN E.F. Modelling and monitoring land-cover change processes in tropical regions. Progress in Physical Geography, 21, 375, 1997.

22. BRIASSOULIS H. Analysis of land use change: Theoretical and modeling approaches. In: The Web Book of Regional Science, West Virginia University: Virginia, 2000.

23. OVERMARS K.P., DE KONING G.H.J., VELDKAMP A. Spatial autocorrelation in multi-scale land use models. Ecological Modelling, 164, 257, 2003.

24. VELDKAMP A., VERBURG P.H. Modelling land use change and environmental impact. Journal of Environmental Management, 72, 1, 2004.

25. GREŠLOVÁ P., GINGRICH S., KRAUSMANN F., CHROMÝ P., JANČÁK V. Social metabolism of Czech agriculture in the period 1830-2010. AUC Geographica, 50 (1), 23, 2015.

26. BOGAERTS T., WILLIAMSON I.P., FENDEL E.M. The role of land administration in the accession of Central European countries to the European Union. Land Use Policy, 19, 29, 2002.

27. BUŚKO M., MEUSZ A. Current status of real estate cadastre in Poland with reference to historical conditions of different regions of the country. Proceedings of the 9th International Conference Environmental Engineering (9th ICEE) Selected Papers, May 22-23, Vilnius, Lithuania, 1, 2014.

28. KOK K., FARROW A., VELDKAMP A., VERBURG P.H. A method and application of multi-scale validation in spatial land use models. Agriculture Ecosystems \& Environment, 85, 223, 2001.

29. PAULEIT S., ENNOS R., GOLDING Y. Modeling the environmental impacts of urban land use and land cover change - a study in Merseyside, UK. Landscape and Urban Planning, 71, 295, 2005.

30. Statistical yearbook of the Małopolskie Voivodeship. Statistical Office: Kraków, 2015 [In Polish].

31. Małopolska: Parki narodowe i krajobrazowe, rezerwaty przyrody (Małopolska: National Parks, Natural Landscape Parks, and Nature Reserves). Marshall Office of the Małopolskie Voivodeship: Kraków, 2010 [In Polish].

32. HERNIK J. Ochrona wrażliwych krajobrazów kulturowych obszarów wiejskich (Protection of sensitive cultural landscapes of rural areas). Zeszyty Naukowe UR w Krakowie: Kraków, 351, 2011 [In Polish].

33. DRZEWIECKI W., WĘŻYK P., PIERZCHALSKI M., SZAFRAŃSKA B. Quantitative and qualitative assessment of soil erosion risk in Małopolska (Poland), supported by an object-based analysis of high-resolution satellite images. Pure and Applied Geophysics, 171, 867, 2014.

34. JANUS J., GŁOWACKA A., BOŻEK P. Identification of areas with unfavorable agriculture development conditions in terms of shape and size of parcels with example of Southern
Poland. Proceedings of the 15th International Scientific Conference on Engineering for Rural Development, May 25-27, Jelgava, Latvia, 15, 1260, 2016.

35. WOCH F., BOREK R. The Role of Management of the Field-Forest Boundary in Poland's Process of Agricultural Restructuring. Papers on Global Change IGBP, 22, 83, 2015.

36. BAŃSKI J., MAZUR M. Classification of rural areas in Poland as an instrument of territorial policy. Land Use Policy, 54, 1, 2016.

37. Analiza struktury władania i użytkowania gruntów w województwie małopolskim w 2015 roku (Analysis of Land Possession and Use Structure in the Małopolskie Voivodeship in 2015). Marshall Office of the Małopolskie Voivodeship: Kraków, 2015 [In Polish].

38. KOLECKA N., KOZAK J. Assessment of the accuracy of SRTM C- and X-band high mountain elevation data: A case study of the Polish Tatra Mountains. Pure and Applied Geophysics, 171, 897, 2014.

39. MANN H.B. Nonparametric test against trend. Econometrica, 13, 245, 1945.

40. KENDALL M.G. A new measure of rank correlation. Biometrika, 30, 81, 1938.

41. DE BEURS K.M., HENEBRY G.M. Land surface phenology, climatic variation, and institutional change: Analyzing agricultural land cover change in Kazakhstan. Remote Sensing of Environment, 89, 497, 2004.

42. JUAHIR H., ZAIN S.M., ARIS A.Z., YUSOF M.K., SAMAH M.A.A., MOKHTAR M.B. Hydrological trend analysis due to land use changes at langat river basin. Environment Asia, 3, 20, 2010 .

43. WRIGHT C.K., WIMBERLY M.C. Recent land use change in the Western Corn Belt threatens grasslands and wetlands. Proceedings of the National Academy of Sciences of the United States of America, 110, 4134, 2013.

44. BLAIN G.C. The modified Mann-Kendall test: On the performance of three variance correction approaches. Bragantia, 72, 416, 2013.

45. RUTKOWSKAA. Statistical methods for trend investigation in hydrological non-seasonal series. Acta Scientiarum Polonorum - Formatio Circumiectus, 12 (4), 85, 2013.

46. YUE S., PILON P., CAVADIAS G. Power of the MannKendall and Spearman's rho tests for detecting monotonic trends in hydrological series. Journal of Hydrology, 259, 254, 2002.

47. BLAIN G.C. Removing the influence of the serial correlation on the Mann-Kendall test. Revista Brasileira de Meteorologia, 29 (2), 161, 2014.

48. BLAIN G.C. The Mann-Kendall test: The need to consider the interaction between serial correlation and trend. Acta Scientiarum-Agronomy, 35, 393, 2013.

49. HAMED K.H., RAO A.R. A modified Mann-Kendall trend test for autocorrelated data. Journal of Hydrology, 204, 182, 1998.

50. YUE S., PILON P. A comparison of the power of the $t$ test, Mann-Kendall and bootstrap tests for trend detection. Hydrological Sciences Journal, 49, 21, 2004.

51. BAYLEY G.V., HAMMERSLEY J.M. The effective number of independent observations in an autocorrelated time series. Journal of the Royal Statistical Society Series B-Statistical Methodology, 8 (2), 184, 1946.

52. MATALAS N.C., LANGBEIN W.B. Information content of the mean. Journal of Geophysical Research, 67, 3441, 1962.

53. LJUNG G.M., BOX G.E.P. On a measure of a lack of fit in time series models. Biometrika, 65, 297, 1978.

54. AKAIKE H. Anew look at the statistical model identification. IEEE Transactions on Automatic Control, 19, 716, 1974. 
55. R Core Team R: A language and environment for statistical computing, R Foundation for Statistical Computing: Vienna, Austria, 2015.

56. MEIYAPPAN P., DALTON M., O’NEILL B.C., JAIN A.K. Spatial modeling of agricultural land use change at global scale. Ecological Modelling, 291, 152, 2014.

57. GINGRICH S., NIEDERTSCHEIDER M., KASTNER T., HABERL H., COSOR G., KRAUSMANN F., KUEMMERLE T., MUELLER D., REITH-MUSEL A., JEPSEN M.R., VADINEANU A., ERB K.H. Exploring long-term trends in land use change and aboveground human appropriation of net primary production in nine European countries. Land Use Policy, 47, 426, 2015.

58. PETERSON U., AUNAP R. Changes in agricultural land use in Estonia in the 1990s detected with multitemporal Landsat MSS imagery. Landscape and Urban Planning, 41, 193, 1998.

59. POŁAWSKI Z. Land use changes in Poland during last two centuries. Teledetekcja Środowiska, 42, 69, 2009 [In Polish].

60. HERNIK J., NOSZCZYK T., PAZDAN M., CZESAK B., STRUTYŃSKI M. Die Transformation ländlicher Räume in Polen. In: Transformation und Landschaft, Kühne O., Gawroński K., Hernik J. (Eds.), Springer VS: Wiesbaden, Germany, pp. 131-144, 2015 [In German].

61. SENETRA A., SZCZEPAŃSKA A., WASILEWICZPSZCZÓŁKOWSKA M. Analysis of changes in the land use structure of developed and urban areas in Eastern Poland. Bulletin of Geography. Socio-economic Series, 24, 219, 2014.

62. ŁOWICKI D. Land use changes in Poland during transformation case study of Wielkopolska Region. Landscape and Urban Planning, 87 (4), 279, 2008.
63. ZYDROŃ A., HAUSA P. Analysis of changes in the structure of land use and ownership after transformation of political and economic system in Poland in 1989 based on selected communes in the Wielkopolska Region. Rocznik Ochrona Środowiska, 12, 909, 2010.

64. SENETRA A., SZCZEPAŃSKA A., WASILEWICZPSZCZÓŁKOWSKA M. The correlations between natural and anthropogenic land-use patterns as a measure of sustainable regional development. Proceedings of the 9th International Conference Environmental Engineering (9th ICEE) - Selected Papers, May 22-23, Vilnius, Lithuania, 2014.

65. HERNIK J., GAWROŃSKI K., DIXON-GOUGH R. Social and economic conflicts between cultural landscapes and rural communities in the English and Polish systems. Land Use Policy, 30, 800, 2013.

66. GĄSIOROWSKI J., POŁAWSKI Z. Land use structure as the basis for indicators determining spatial development of the environment. Polish Journal of Environmental Studies, 23, 955, 2014.

67. LOEHR D. External costs as driving forces of land use changes. Sustainability, 2, 1035, 2010.

68. HERNIK J., CZESAK B., NOSZCZYK T., PAZDAN M. Cultural landscape and land use in the rural areas of Poland. In: Cultural landscapes in the context of socio-economic changes in Poland and China, Hernik J., Chen G., Gawroński K. (Eds.), Publishing House of the University of Agriculture in Krakow: Krakow, Poland, pp. 11-21, 2015. 